\title{
Enzyme Inhibitor
}

National Cancer Institute

\section{Source}

National Cancer Institute. Enzyme Inhibitor. NCI Thesaurus. Code C471.

A pharmacological agent that inhibits the catalytic activity of an enzyme. 